\title{
Countermeasures Research on the Participation of Chinese Port in the "One Belt and One Road" Construction
}

\author{
Xi Yao ${ }^{1, a^{*}}$, Yuan Gao ${ }^{1, b}$ and Houming Fan ${ }^{1 \mathrm{c}}$ \\ ${ }^{1}$ Transportation Management College, Dalian Maritime University, Dalian, China

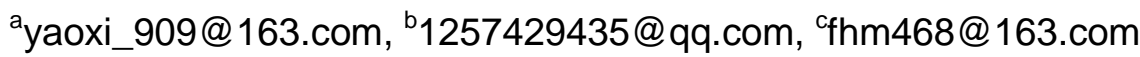

Keywords: One belt and one road; Port group; Opportunities; Strategy

\begin{abstract}
Ocean shipping plays an important role in promoting the economic development of China. This paper systematically analyzes the development opportunities that the "One Belt and One Road" strategy brings to the three major port groups of China, and points out that the port groups should incorporate their own development to the new global trade network based on their location and port resources endowment, make themselves become the vanguard and main force of the construction of 21st-Century Maritime Silk Road and be contributed to the development of the economy and trade of China and the world. The research results can provide references for the related decision-making of Chinese port participation in the "One Belt and One Road" construction.
\end{abstract}

\section{Introduction}

In order to enhance the level of China's opening to the outside world, deepen the interconnection of Asia, Europe and Africa continent and nearby oceans, and achieve common prosperity and development of all the countries in the world, Chinese president Xi Jinping proposed the strategic conceptions of building the Silk Road Economic Belt and 21st-Century Maritime Silk Road ("One Belt and One Road") in succession in Kazakhstan and Indonesia in September and October, 2013. The "One Belt and One Road" strategy helps to create a new pattern of China's all-round opening up, expand regional development space and promote world peace.

With the "One Belt and One Road" strategy put forward, domestic scholars have begun to study its influence on the politics, economy and strategic layout. L. Jin [1] refuted that some scholars compared the "One Belt and One Road" strategy to the Chinese version Marshall plan, noting that the "One Belt and One Road" is national strategy with the common development as the basic attribute, the principle of equality and mutual benefit, pragmatic cooperation oriented. M.N. Zhang [2] pointed out the risks and challenges in the implementation of the current "One Belt and One Road" strategy, proposing the policy suggestions that the "One Belt and One Road" should be comprehensively deepen in terms of the concept, mode and strategy. H. Dong and H.H. Lin [3] discussed domestic enterprises how to better participate in the "One Belt and One Road" strategy and effectively avoid and solve trade friction problem from the economic point of view. With the new situation of international and regional economic cooperation considered, X.J. Shen and J.C. Xiao [4] pointed out the important strategic significance of China's implementation of the "One Belt and One Road" construction and thought on the key points of construction. J.G. Huang and X.P. Luo [5] came up with the idea that it needs the joint operation of national, provincial and district levels to construct the 21st-Century Maritime Silk Road, and it should focuses on the construction of the system and integrated thinking mode. F.S. Wang, H.B. Cong and C.X. Ji [6] studied the necessity and advantages of Ningbo - Zhoushan port to participate in the "One Belt and One Road" construction, putting forward the measures that Zhoushan port should take to connect the "One Belt and One Road". J. Sun [7] elaborated that as the intersection of "One Belt and One Road", Lianyungang needs joint effort and cooperation at all levels to bring its location advantage into full paly. J.Y. Liu and L.Q. Zhao [8] studied the logistics development problem of Tianjin port under the "One Belt and One Road" strategy. Q.C. Zeng [9] analyzed the characteristics of shipping logistics system under the background of the Maritime Silk Road and expounded the development situation and problems of ports along the Maritime Silk Road. 
From the existing literature, the research on the closely related port industry to the "One Belt and One Road" strategy is less, especially the lack of research to explore the positioning and countermeasures of port groups from the national level. However, the port is the front window of a country opening to the outside world and the important hub of domestic and international trade, playing an important role in the pattern of the "One Belt and One Road" strategy. Therefore, the countermeasures research of Chinese ports to participate in the "One Belt and One Road" construction is necessary and has important strategic significance.

\section{New Opportunities of the "One Belt and One Road" Bringing to Chinese Ports}

The "One Belt and One Road" construction brings new opportunities to Chinese ports, as shown in Figure. 1, The "One Belt and One Road" strategy covers a very wide range of areas and node cities, and it is China's future opening grand strategy. The "One Belt and One Road" includes 65 countries and 4.4 billion people, accounting for $63 \%$ of the world's population. The economic capacity of these countries is approximately $\$ 21$ trillion, taking up $29 \%$ of the world economic capacity. The annual growth rate of the whole foreign trade and foreign capital inflows along the "One Belt and One Road" are $13.9 \%$ and $6.5 \%$ respectively, which are much high than the average growth of the whole word. The "One Belt and One Road" is more the new driving force of global development that China looks for in the global economic malaise than the process that China actively goes through to promote emerging economic integration through geographical layout. In fact, the outbreak of the financial crisis in 2008 broke the original old model of "consuming in the west, making in the east". The international division of labor has been restructured. Profound changes have taken place in the world economic pattern. The international division of labor in developing countries begins to ascend. The world trade center and the international shipping center began moving eastward to the Asia-Pacific region. The proposal of the "One Belt and One Road" is exactly to cater to this trend.

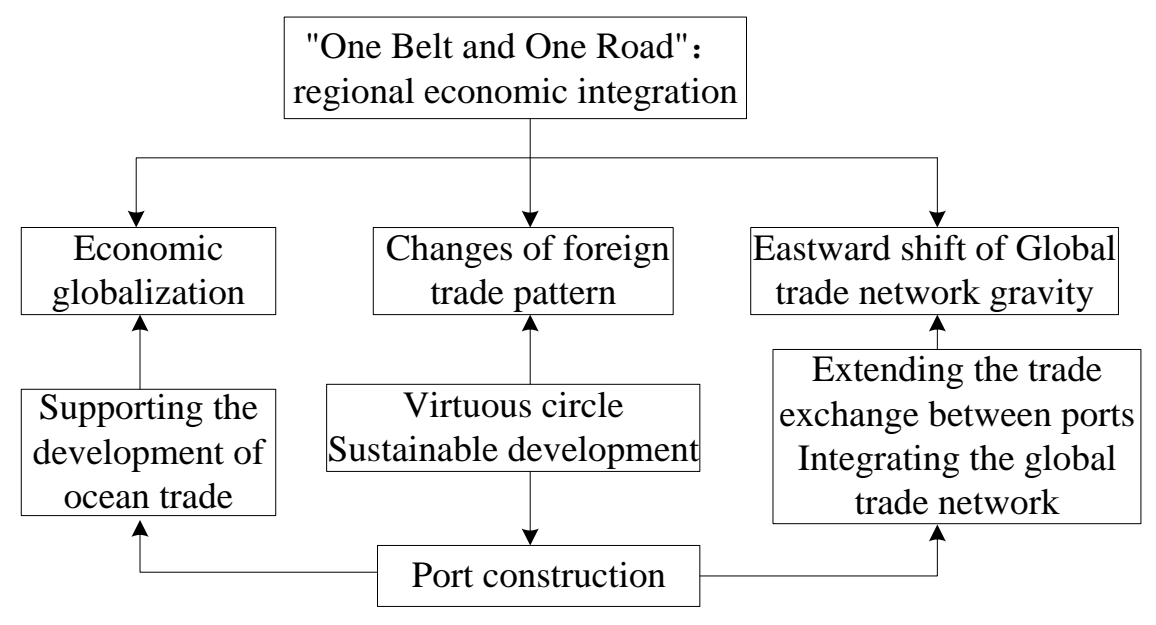

Figure 1. New Opportunities of the "One Belt and One Road" Bringing to Chinese Ports

In recent years, as the macroeconomic growth continually slows down, cargo throughput growth rate of China's above-scale port is also showing a slowing trend in general [10]. From 2000 to 2008, China's ports have maintained the momentum of rapid growth with the average annual growth rate of $15 \%$ and above. Affected by the global financial crisis in 2008, the growth rate has slowed. At the same time, due to the rapid and blind expansion of ports in recent years, the structural overcapacity and disorderly competition problem of ports became highlighted. Currently, domestic supply is limited, and most ports of China are in a hungry state, so the major ports are trying to find sources of goods from other countries. Dropping from high growth to low growth, the ports of China officially entered into the "new normal". The proposed "One Belt and One Road" strategy coincides with Chinese ports in such a "new normal" period. There is no doubt that it provides a 
way out for the development of ports in the new era and brings new historical opportunity for the transformation and upgrading of ports.

More than $85 \%$ of China's international trade goods are transported through the international shipping. As the infrastructure of international goods transport hub, the construction of ports supports the development of maritime trade. Under the background of the "One Belt and One Road" construction, Chinese ports will face new opportunities and challenges. They should incorporate themselves into the new global trade network to realize the all-round opening up to the outside world and accelerate the pace of building modern, intelligent and international ports, calmly facing the change of future.

\section{Strategic Positioning and Countermeasures of Chinese Ports in the "One Belt and One Road"}

In March 2015, China's National Development and Reform Commission, the Ministry of Foreign Affairs and the Ministry of Commerce announced "the Vision and Actions on Jointly Building Silk Road Economic Belt and 21st-Century Maritime Silk Road ", the main content and key point of which are shown in Table 1, The "One Belt and One Road" broke China's traditional dot-block development pattern. It transversely runs through the east-central-west regions, and longitudinally connects the major sea port cities. At the same time, it promotes the eastern coastal area opening to the outside world and speeds up the pace of the Midwest less developed areas. The "One Belt and One Road" core region involves in 18 provinces, and determines 15 sea ports as "weight" of the infrastructure construction. In view of "One Belt and One Road" strategy, how to position the three largest port groups and how to develop and formulate corresponding developmental policy have become a public concern.

Table 1 The main content and key point of "One Belt and One Road"

\begin{tabular}{|c|c|}
\hline Main content & Key Point \\
\hline $\begin{array}{c}\text { Silk Road } \\
\text { Economic Belt }\end{array}$ & $\begin{array}{c}\text { Focusing on bringing together China, Central Asia, Russia and Europe } \\
\text { the Baltic); linking China with the Persian Gulf and the Mediterranean } \\
\text { Sea through Central Asia and West Asia; and connecting China with } \\
\text { Southeast Asia, South Asia and the Indian Ocean }\end{array}$ \\
\hline $\begin{array}{c}\text { 21st-Century } \\
\text { Maritime Silk Road }\end{array}$ & $\begin{array}{c}\text { Going from China's coast to Europe through the South China Sea and } \\
\text { the Indian Ocean in one route, and from China's coast through the } \\
\text { South China Sea to the South Pacific in the other }\end{array}$ \\
\hline $\begin{array}{c}\text { Constructing } \\
\text { economic corridors }\end{array}$ & $\begin{array}{c}\text { Jointly building a new Eurasian Land Bridge and developing } \\
\text { China-Mongolia-Russia, China-Central Asia-West Asia, } \\
\text { China-Indochina Peninsula economic corridors }\end{array}$ \\
\hline
\end{tabular}

Bohai Port Group. In the three major port groups of the national layout planning, Bohai port group is basically connected to the hinterland by railway and highway, which is different from the southeast coastal ports that are supported by the developed water system. Therefore, Bohai port group should rely on the three northeast provinces, Beijing-Tianjin-Hebei in North China and Shandong and Henan in the central plains, playing a prominent role in the construction of China-Mongolia-Russia economic corridor, the new Eurasian Continental Bridge and the Arctic navigation. At the intersection of China-Mongolia-Russia economic corridor and new Eurasian Continental Bridge economic belt in the Silk Road Economic Belt, Bohai port group has an important advantage to radiate the central and western regions and lead to the connectivity of Asian and European market with convenient rail access to Alashankou. Bohai port group should seize the strategic opportunities of the "One Belt and One Road" and coordinate the strategies of Beijing-Tianjin- Hebei integration, Tianjin free trade zone, China and Korea free trade zone and the Northeast Asia Economic Circle, realizing rapid development. 
Bohai port group should focus on strengthening the connection and integration of the Continental Bridge and the "One Belt and One Road", improves the multimodal transport system, and enhance the entrepot trade service function in the neighboring countries and regions. After the opening of the Arctic northeast route, the distance from ports in north China to Europe by the Arctic route is significantly reduced compared with the traditional route. Due to the abundant oil and gas resources in the Arctic, the opening of the Arctic northeast route can enable China to form a more perfect energy security network. Consequently, Bohai ports should strengthen the construction of port infrastructure and hinterland to achieve the trade link of the Arctic route and the "One Belt and One Road". For example, with large crude oil terminal, Qingdao and Dalian are equipped with relatively complete energy discharging condition, and they can take advantage of this condition to be built into an international energy hub in the Arctic route. Tianjin, as the only port which owns three transit trains and has been approved for the construction of the free trade experimental area, should rely on the connection function of the Eurasian Continental Bridge, vigorously develop sea-railway combined transport and play the role of Mongolia and Russia economic corridor key nodes and maritime cooperation fulcrum.

Yangtze River Delta Port Group. The Yangtze River Delta port group is the most densely distributed and the maximum throughput port group in China's coastal port group port, and is closely related to the two Silk Road of sea and land in the history. Located in the center of the eastern coast of China with developed waterway transportation, the Yangtze River Delta region has formed the pattern of international shipping center with Shanghai as the center, Jiangsu and Zhejiang as the two wings. The Yangtze River Delta port group is supposed to be the main force of the "One Belt and One Road" construction. Thus, the Yangtze River Delta port group should take an active part in docking the "One Belt and One Road". Shanghai port and Ningbo-Zhoushan port should invest heavily in the construction of sea-railway combined transport line, while Lianyungang is able to sign a cooperation agreement with Kazakhstan, Kyrgyzstan, Lithuania and so on, creating a two-way opening-up layout. As a direct access of the new Eurasian Continental Bridge to the sea, the Yangtze River Delta port group plays an important role in the construction of the new Eurasian Continental Bridge Economic Belt in the "One Belt and One Road" strategy along land bridge logistics transportation corridor. It is through the core area of the sea and inland transportation.

Situated in the center of the north-south coastline of China and backed by the developed Yangtze River waterway, the Yangtze River Delta port group has superior geographical position, facing the Pacific Ocean. It has close contact with Bohai ports in the north, and cooperates with the Pearl River delta ports in the south. The Yangtze River Delta port group has two major ports, whose hinterland lies in the Yangtze River Delta region where the economy is the most active. After the implementation of the "One Belt and One Road" strategy, the freight volume of the two ports will increase rapidly. For the Yangtze River Delta port group, the first task at present is to carry out information construction to improve operating efficiency of the port, effectively enhancing the overall competitiveness. With respect to the Bohai port group, the Yangtze River Delta port group is relatively dense, which leads to more intense competition and serious overlapping of port function. Therefore, the function, position and layout within port group are particularly important to the coordinated development of the Yangtze River Delta ports. The reform of Shanghai free trade zone and the construction of Shanghai international shipping center should be further deepen. Ningbo-Zhoushan port should play the advantage of deep-water resources to establish international deep-water hub port. The Yangtze River Delta ports should strengthen the cooperation and communication with nearby ports, promote the dislocation development of the ports within the region, and coordinate with each other to expedite the comprehensive development of the Yangtze River Delta region.

Pearl River Delta Port Group. The Pearl River Delta port group has the advantage of excellent geographical location. Located in the coastal area of southeast China, the Pearl River Delta port group is adjacent to Hong Kong, Macao and Taiwan, and trades with Southeast Asia frequently. The development of market economy and export-oriented economic in the region is relatively perfect. The Pearl River Delta is the forefront of China's foreign trade, and has close contact with 
the Association of Southeast Asian Nations (ASEAN), the first station of 21st-Century Maritime Silk Road. Connecting China - Indochina economic corridor, the Pearl River Delta port group is closely related to the Pearl River Delta economic zone, the Beibu Gulf economic zone, Fujian free trade zone and Haixi free trade zone. As an important starting point of Maritime Silk Road, the Pearl River Delta port group has an important effect on enhancing the exchanges with countries and regions along the road and developing 21st-Century Maritime Silk Road economic corridor that faces South Sea, Pacific Ocean and Indian Ocean.

Ports of south China, including the Pearl River Delta port group, the hinterland of which have developed river network and convenient water transport, should focus on the development of regional river-ocean combined transportation system and accelerate the interconnection of the Maritime Silk Road and river channel. The southwest region of China has frequent trade with the ASEAN. The ASEAN, as the core area of Maritime Silk Road Economic Belt and China's third largest trade partner, performs an important function in the economic development of the southwest region of China. The Pearl River Delta port group should be actively involved in the major infrastructure construction of the ports of ASEAN, open maritime logistics channel according to the commerce industry, and get through the trade barriers of China - Indochina economic corridor. In addition, it should make use of the advantage of Guangdong near Hong Kong and Macao regions to enhance the cooperation with Hong Kong, Macao and Taiwan and speed up the construction of the Guangdong, Hong Kong and Macao free trade zone, playing the role of external linkage of free trade zone. The port resources and economic of the Pearl River Delta region should be reasonably integrated to achieve the common development of the whole port group.

Although the "One Belt and One Road" strategy brings great opportunities for the major development of ports, it also puts forward higher requirements for the relevant port information monitoring, logistics docking, operation management and port service function. As a result, the innovation, information and intelligence transformation of major ports is imperative. Ports should catch the opportunity of the "One Belt and One Road" to optimize the port management models through the Internet of things, big data and cloud computing, which is necessary requirements for the port to respond to future international economic cooperation.

\section{Conclusion}

Ocean shipping plays an important role in promoting the economic development of China. Under the background of the "One Belt and One Road" construction, the three major port groups should seize the opportunity to incorporate their own development to the new global trade network based on their location and port resources endowment, and make contribution to the development of the economy and trade of China and the world.

\section{Acknowledgements}

This work was supported by national natural science foundation of china (NO.61473053) and the Social Science Fund of Liaoning Province (Grant No. L15BJY041).

\section{References}

[1] L. Jin: International Studies, (2015) No.1, p.88. (In Chinese)

[2] M.N. Zhang: Macroeconomic Management, (2015) No.2, p.20. (In Chinese)

[3] H. Dong and H.H. Li: China Business and Market, (2015) No.5, p.119. (In Chinese)

[4] X.J. Shen and J.C. Xiao: Macroeconomics, (2014) No.11, p.30. (In Chinese)

[5] J.G. Huang and X.P. Luo: Journal of Zhejiang Ocean University (Humanities Science), Vol.31 (2014) No.1, p.1. (In Chinese)

[6] F.S. Wang, H.B. Cong and C.X. Ji: Economic Forum, Vol.534 (2015) No.1, p.57. (In Chinese) 
[7] J. Sun: Journal of Jiangsu University (Social Science Edition), Vol.17 (2015) No.4, p.39. (In Chinese)

[8] J.Y. Liu and L.Q. Zhao: Logistics Technology, Vol.34 (2015) No.7, p.29. (In Chinese)

[9] Q.C. Zeng: Development Report of Ports along 21st-Century Maritime Silk Road (Dalian Maritime University Press, China 2015). (In Chinese)

[10] C.J. Liu: China Port, Vol.7 (2015), p.10. (In Chinese) 